\title{
New Record of the Genus Hydrotaea Robineau-Desvoidy, 1830 (Diptera, Muscidae) from Kerbala City, Iraq
}

\author{
Haider Naeem Al-Ashbal ${ }^{1}$, Rafid Abbas Al-Essa ${ }^{1}$, Hanaa H. Al-Saffar ${ }^{2}$ \\ ${ }^{1}$ College of Education for Pure Sciences/ University of Kerbala, Kerbala, Iraq, ${ }^{2}$ Iraq Natural History Research \\ Center and Museum, University of Baghdad, Baghdad, Iraq
}

\begin{abstract}
The current study showed the genus Hydrotaea Robineau-Desvoidy, 1830 recorded for the first time to Iraqi entomofauna and with its two species H.aenescens (Wiedemann, 1830) and H. albuquerquei Lopes, 1985. The specimens collected from carcasses of dogs. The photos taken by the aid of dino light digital microscope. The identification of diagnostic characters by using many taxonomical keys.
\end{abstract}

Key words: Diptera, Forensic Entomology, Hydrotaea, Iraq, Muscidae, Ophyra.

\section{Introduction}

The genus Hydrotaea Robineau-Desvoidy, 1830, belongs to the family Muscidae and is widespread in Palearctic and temperate regions around the world ${ }^{(1)}$. This genus Hydrotaea includes more than 130 species (2-3).

The members of Hydrotaea species were diagnosed by body color metallic black, blue or green or not shining; the compound eyes of male are holoptic and bare; female ocellar triangle shining, short or long, sometimes reaching lunula; antenna dark sometimes with pale base, aristae very short pubescent; gena with or without reclinate strong differentiated seata, the palpi orange- dark black. Thorax with dorsocentral bristles $(2+4)$, notopleuron with two setae equal in size and covered with setulae; anepimeron bare; sub Costa is raining with a fine curve from humeral Cross-vine to Costa, medial vein straight.

Some authors showed the junior synonyms of Hydrotaea is Ophyra Robineau-Desvoidy 1830, such as: ${ }^{(2-5)}$ with diagnostic features as body usually metallic black. Fronto-orbital seta of female are weak and shorter than frontal setae. Ocellar triangle of female almost long and reaching the lunule, gena without setae ${ }^{(6-8)}$.

These species of Hydrotaea are environmentally important because of their eating habits as predators as well as their presence near residential areas. which are natural sweepers for the disposal of waste and recycling in the environment, so some countries have been breeding and proliferation in nature, as they do not enter the housing does not cause any inconvenience to humans as well as their importance in research Criminal $(9,10)$.

Several studies have been conducted on this genus, which contributed to determining the age of the body and time of death (PMI). That its occurrence on human bodies abundantly in the late stages of decomposition within the graves of the burial of the dead, which gave it special importance in future criminal studies (6) (1116). The larvae of Hydrotaea species are predators of the other dipteran larvae and therefore seen in the later stages of decomposition ${ }^{(2,10)}$.

This species of Hydrotaea generally associated with environments where temperatures are mild throughout the year as it significantly affects the distribution and growth of these insects, in particular on the immature stages ${ }^{(17-19)}$.

\section{Materials and Method}

In this study the specimens were collected from dog carcasses during the period from $1 / 3 / 2018$ to $28 / 2 / 2019$, which killed by two methods the first using a sharp knife and the second by a toxic substance (Strychnine sulfatetablet). Use three duplicates in each of the abovementioned transactions. The flies collected by air net and fly roll trap during the bloating and decaying stages of 
carcasses. The specimens were taken to the laboratory and killed by freezing (24h) and so as they mounted by insect pins, the locality and date of collection were recorded ${ }^{(20,21)}$.

For identification of genus and species were used taxonomical keys such as (6, 7) (16) (22-26) The habitat and morphological features taken photos by the aid of the digital microscope dino-light with scales of measurements.

\section{Results and Discussion}

In the present study, the genus Hydrptaea Robineau-Desvoidy, 1830 and its species, H.aenescens and $H$. albuquerquei, recorded as new to Iraqi fauna.

\section{Hydrotaea Robineau- Desvoidy, 1830}

Synonym: Ophyra Robineau- Desvoidy, 1830

Ophira Rondani, 1856

Osphyra Meade, 1830

Alloeonota Schnabl, 1911

\section{Diagnostic characteristics of the genus Hydrotaea} Robineau-Desvoidy, 1830:

These genes can be identify by the diagnosis characters. The body is shining blue-black species (Pl. 1 $\mathrm{A}, \mathrm{B})$; the compound eyes of male is holoptic, while in female is dichoptic (Pl.2 A, B); the gena with no distinct setae, frons with the shining ocellar triangle extended more than halfway from front ocellus to lunule (almost reaching to lunule) without dusting.

Key to the two species of Hydrotaea RobineauDesvoidy, 1830

1- Maxillary palp orange-yellow in color (P1. 4 A); ocellar triangle with a blunt end (pl.3 A), Hind trochanter, on ventral surface, with tuft of fine, hooked setae (pl.5) H. aenescens (Wiedemann, 1830)
2- Maxillary palp black-dark brown (Pl.4B); ocellar triangle with a sharp end (pl. 3 B), Hind trochanter, on ventral surface, without tuft of fine setae. H. albuquerquei Lopes, 1985

\section{Hydrotaea aenescens (Wiedemann, 1830)}

Common name: America black dump fly

Synonym: Anthomyia aenescens Wiedemann, 1830

Anthomyia aenescens (Wiedemann, 1830)

Crssopalpus aenescens (Wiedemann, 1830)

Ophyra trochanterata Malloch, 1932

Materials examined (37 specimens), at blotting

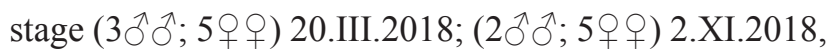
at decaying stage $(9 \circ \circ ; 6 \hat{\jmath})$ 21.III. 2018; (2へ̂; 5우우) 3-20.XI. 2018.

Distribution: America (27); Hungary (28); Lebanon, Tunisia, Egypt, Morocco, Britian and Irlend ${ }^{(29)}$; Turkey (30); Argentina (24) as Ophyra aenescens; Belgian cost (31); Portugal (32); Argentina ${ }^{(23)}$; Finland ${ }^{(33)}$; Weatren Palaearctic Region ${ }^{(10)}$; Bulgaria ${ }^{(8)}$.

\section{Hydrotaea albuquerquei Lopes, 1985}

Common name: black dump fly

Synonym: Hydrotaea oides Skidmore, 1985

Ophyra albuquerquei Lopes, 1985

Materials examined (30 specimens), at blotting

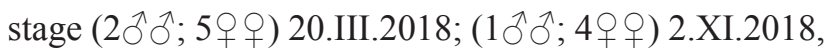

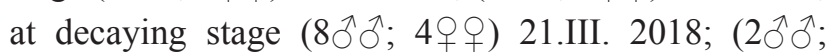
4우우) 3-20.XI. 2018.

Distribution: Brasil (17) (34); Neotropical Region (35); South America ${ }^{(6)}$; in southern Brazil ${ }^{(36)}$; Peru ${ }^{(37)}$. 


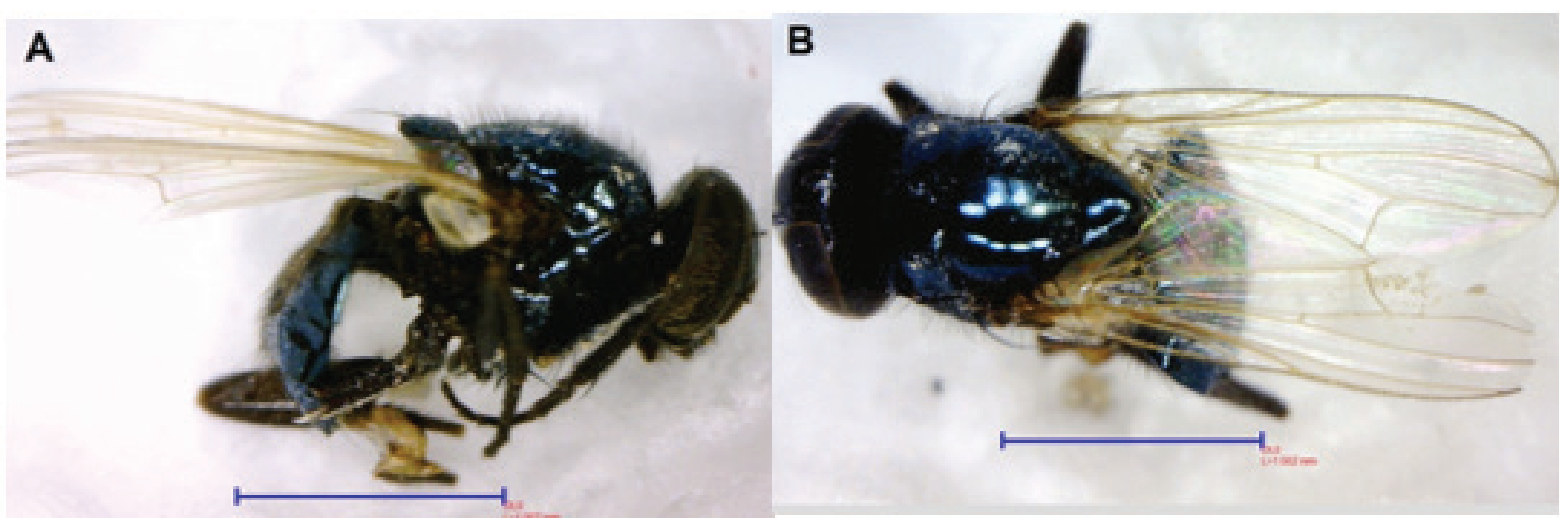

Plate (1): Hydrotaea aenescens; (A) Male, lateral view
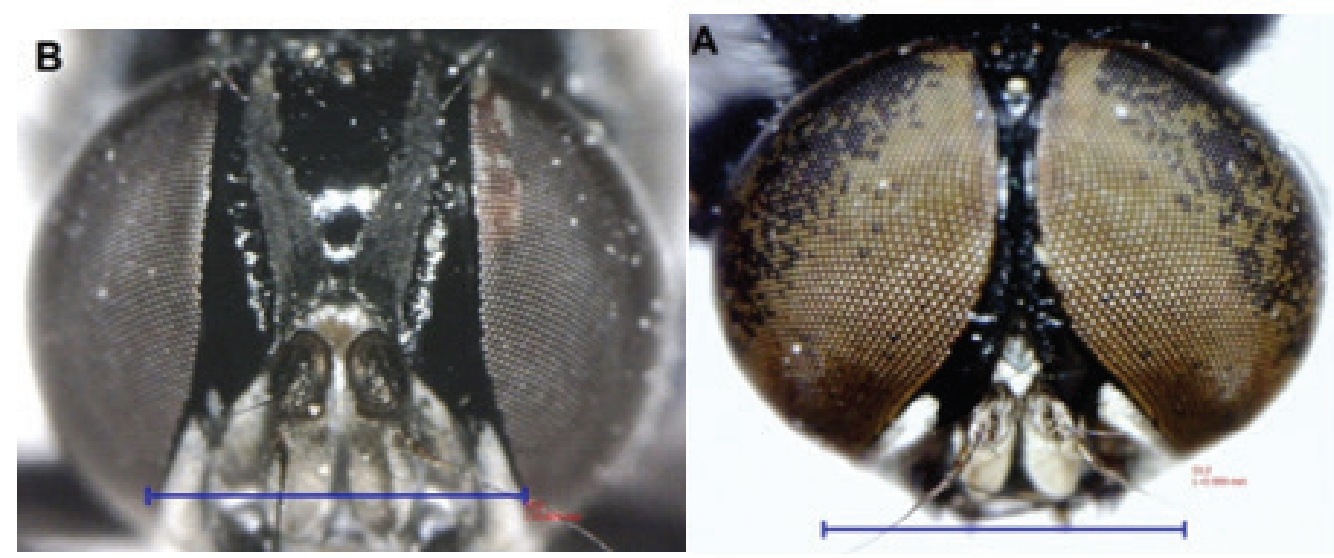

Plate (2): head of $H$. albuquerquei; (A) Male (B) female

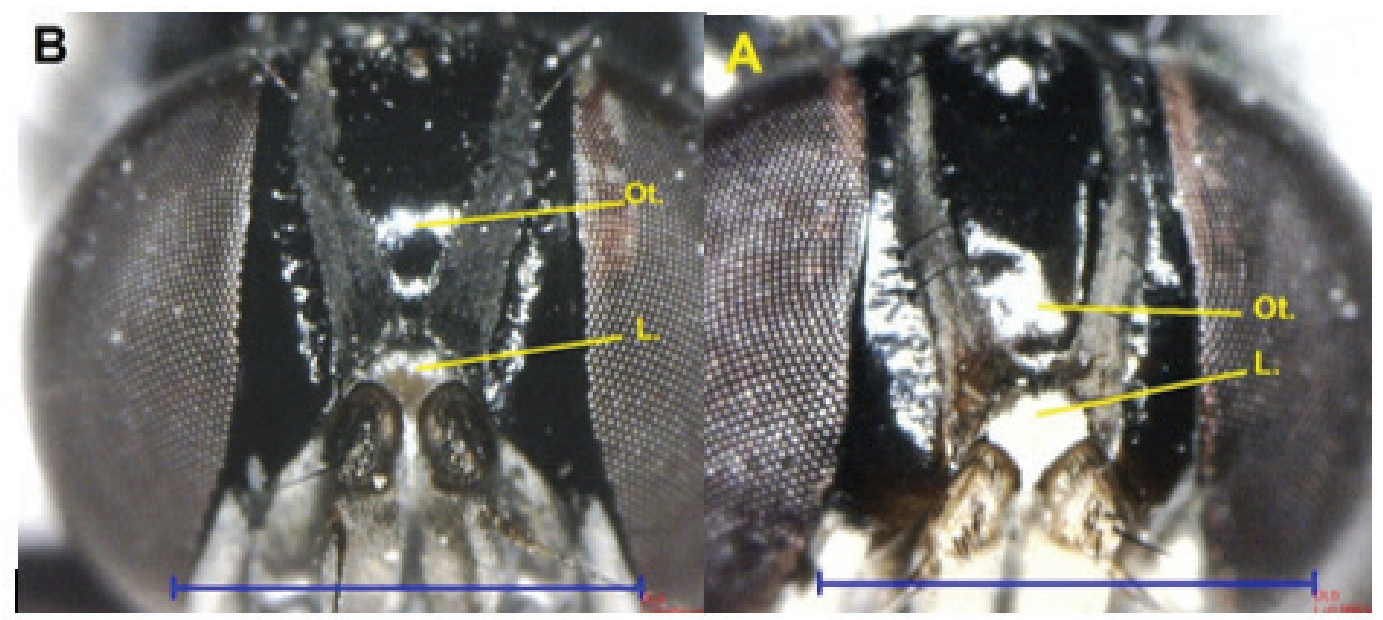

Plate (3): head of female; (A) H. aenescens; (B) H. albuquerquei

L. =lunule; Ot. $=$ Ocellar triangle 


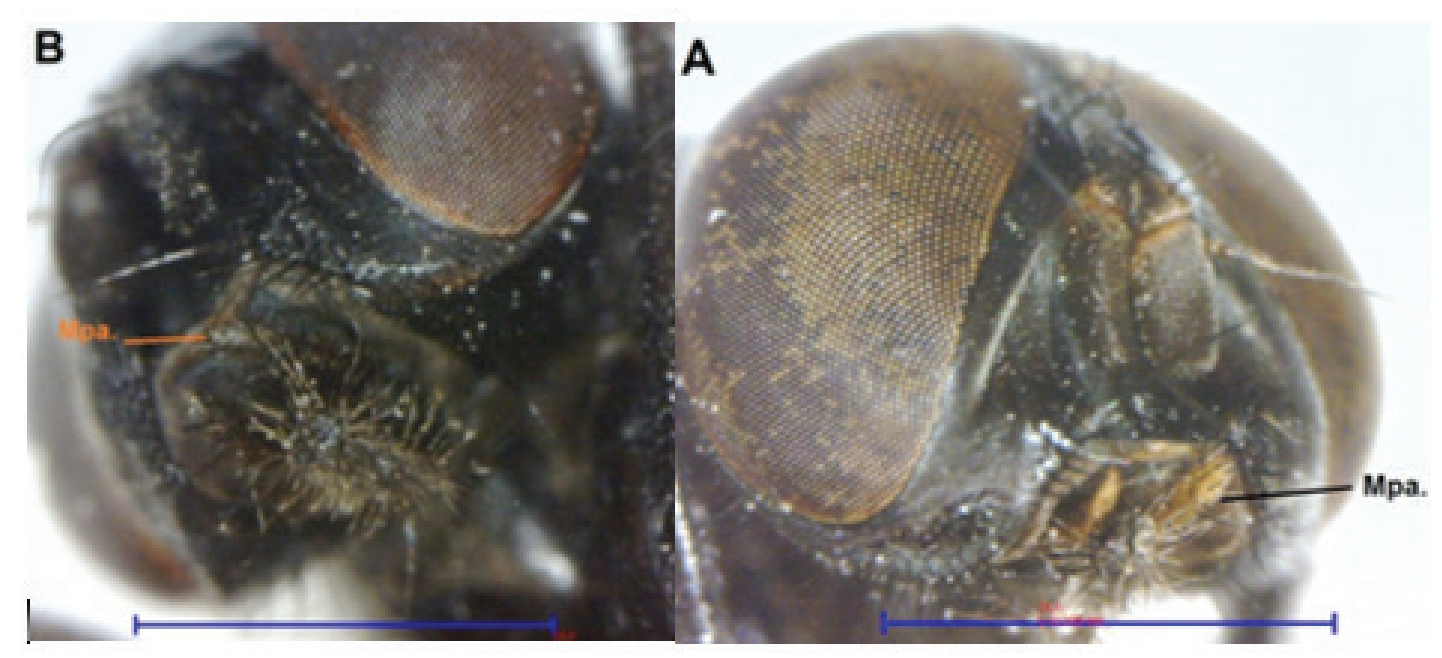

Plate (4): head of male; (A) H. aenescens; (B) H. albuquerquei

$$
\text { Mpa. }=\text { maxillary palp }
$$

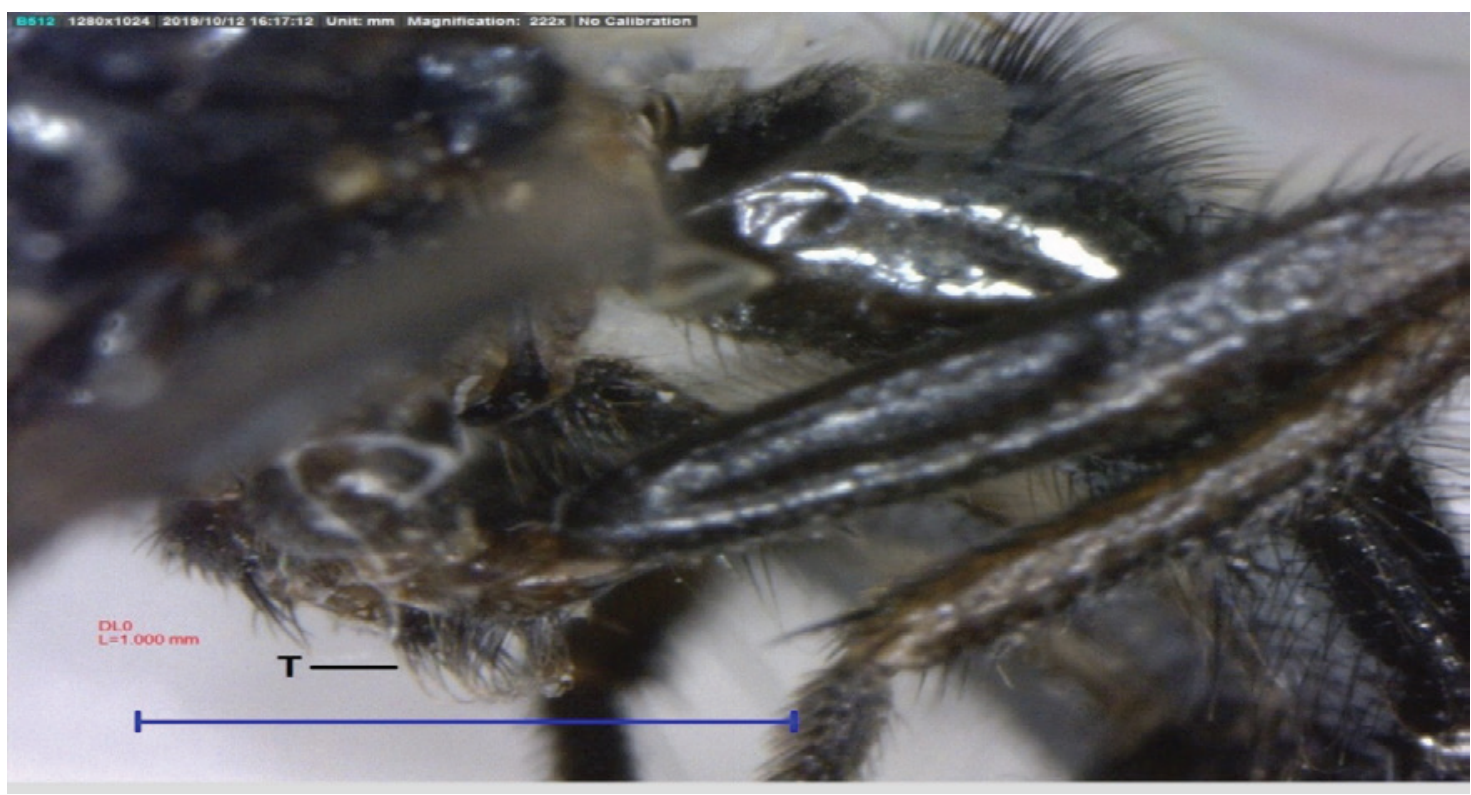

Plate (5): hind leg of $H$. aenescens $\mathbf{T} .=$ tuft, lateral view,

Ethical Clearance: The Research Ethical Committee at scientific research by ethical approval of both MOH and MOHSER in Iraq

\section{Conflict of Interest: Non}

Funding: Self-funding

\section{References}

1. Couri, M. S., Cunha, A. M., Souza, S. M. F. M. de, and Laeta, M. 2009. Ophyra capensis (Wiedemann) (Diptera, Muscidae) found inside the esophagus of a mummy in Lisbon (Portugal). Papéis Avulsos de Zoologia, 49(6): 87-91.

2. Skidmore, P. 1985. The biology of the Muscidae of the world.-Series Entomologica 29: xiv+ 550pp.; $D r . W$. Junk Publishers, Dordrecht.

3. Savage, J., and Wheeler, T. A. 2004. Phylogeny of the Azeliini (Diptera: Muscidae). Studia Dipterologica, 11: 259-299. 
4. Pont, A. C. 1989. 107. Family Muscidae. Catalog of the Diptera of the Australasian and Oceanian Regions. Special Publications of the Bernice Pauahi Bishop Museum, 86(1155): 675-699.

5. Carvalho, C. J. B. de, Moura, M. O., and Ribeiro, P. B. 2002. Chave para adultos de dípteros (Muscidae, Fanniidae, Anthomyiidae) associados ao ambiente humano no Brasil. Revista Brasileira de Entomologia, 46(2):107-144.

6. Carvalho, C. J. B. de, and Mello-Patiu, C. A. de. 2008. Key to the adults of the most common forensic species of Diptera in South America. Revista Brasileira de Entomologia, 52(3):390-406. https:// doi.org/10.1590/s0085-56262008000300012

7. Couri, M. S. 2010. Key to the Australasian and Oceanian genera of Muscidae (Diptera). Revista Brasileira de Entomologia, 54(4):529-544.

8. Zielke, E. 2018. On two remarkable species of Azeliinae (Diptera: Muscidae), previously unknown from the Balkans, but collected from Bulgaria already in the 20th century. Historia Naturalis Bulgarica, 30: 1-5.

9. Mądra, A., Frątczak, K., Grzywacz, A., and Matuszewski, S. 2015. Long-term study of pig carrion entomofauna. Forensic Science International, 252: 1-10.

10. Grzywacz, A., Ogiela, J., and Tofilski, A. 2017. Identification of Muscidae (Diptera) of medicolegal importance by means of wing measurements. Parasitology Research, 116(5): 1495-1504.

11. Oliva, A. 1997. Insectos de interés forense de Buenos Aires (Argentina): Primera lista ilustrada y datos bionómicos. Museo Argentino de Ciencias Naturales Bernardino Rivadavia e Instituto ....

12. Oliva, A. 2001. Insects of forensic significance in Argentina. Forensic Science International, 120(12): $145-154$.

13. Aballay, F. H., Murúa, A. F., A Costa, J. C., and Centeno, N. 2008. Primer registro de artropodofauna cadavérica en sustratos humanos y animales en San Juan, Argentina. Revista de La Sociedad Entomológica Argentina, 67(3-4): 157-163.

14. Rosa, T. A., Babata, M. L. Y., Souza, C. M. de, Sousa, D. de, Mello-Patiu, C. A. de, and Mendes, J. 2009. Dípteros de interesse forense em dois perfis de vegetação de cerrado em Uberlândia, MG. Neotropical Entomology, 38(6): 859-866.

15. Grzywacz, A., Hall, M. J. R., Pape, T., and Szpila, K.
2017. Muscidae (Diptera) of forensic importancean identification key to third instar larvae of the western Palaearctic region and a catalogue of the muscid carrion community. International Journal of Legal Medicine, 131(3):855-866.

16. Hore, G., Saha, G. K., and Banerjee, D. 2018. Sensory organs of forensically important fly Ophyra capensis (Wiedemann, 1818) (Diptera: Muscidae): A scanning electron microscopic study. Acta Tropica, 185: 400-411.

17. Costa, P. R. P., Franz, R. L., Vianna, E. E. S., and Ribeiro, P. B. 2000. Synanthropy of Ophyra spp. (Diptera, Muscidae) in Pelotas, RS, Brazil. The Revista Brasileira de Parasitologia Veterinária, 9(2): 165-168.

18. Ribeiro, P. B., Carvalho, C. J. B. de., Regis, M.and Costa, P. R. P. (2001). Exigências térmicas e estimativa do número de gerações de Ophyra aenescens Wiedemann, 1830 (Diptera, Muscidae, Azeliinae), em Pelotas, RS. Arq Inst Biol, 68, 7582.

19. Lefebvre, F., and Pasquerault, T. 2004. Temperature-dependent development of Ophyra aenescens (Wiedemann, 1830) and Ophyra capensis (Wiedemann, 1818)(Diptera, Muscidae). Forensic Science International, 139(1): 75-79.

20. Al Al-ashbal, H. N., AL-Essa, R. A. and AbdulRassoul, M. S. 2015. Survey and diagnostic insect parasites that infect the pupa of house flies Musca domestica Linn. (Diptera:Muscidae) in some region of Karbala. Journal of Kerbala University, 10(4): 271-289.

21. Al-Mesbah, H. 2010. A study of forensically important Necrophgous Diptera in Kuwait. July, 1-136. https://doi.org/10.1081/E-EOE

22. Assis Fonseca, E. C. M. 1968. Diptera Cyclorrhapha Calyptrata Section (b) Muscidae. Handbooks for the Identification of British Insects, 10(b), 4.

23. Patitocci L. D., Mulieri, P., Olea, M.S. and Mariluis, C. 2013. Muscidae (Insecta: Diptera) of Argentina: revision of Buenos Aires province fauna, with a pictorial key to species. Zootaxa, 3702(4): 301347.

24. Patitocci L. D., Mulieri, P., Oliva, A. and Mariluis, C. 2010. Status of the forensically important genus Ophyra (Diptera: Muscidae) in Argentina. Revista de La Sociedad Entomológica Argentina, 69(1-2): 91-99. 
25. Carriço, C., Mendonça, P. M., Cortinhas, L. B., Mallet, J. R. dos S., and Queiroz, M. M. de C. 2015. Ultrastructural studies of some character of Diptera (Muscidae) of forensically importance. Acta Tropica,142:96-102. https://doi.org/10.1016/j. actatropica.2014.11.005.

26. Morrow, J. J., Baldwin, D. A., Higley, L., PiombinoMascali, D., and Reinhard, K. J. 2015. Curatorial implications of Ophyra capensis (Order Diptera, Family Muscidae) puparia recovered from the body of the Blessed Antonio Patrizi, Monticiano, Italy (Middle Ages). Journal of Forensic and Legal Medicine, 36: 81-83. https://doi.org/10.1016/j. jflm.2015.09.005.

27. Sabrosky, C. W. 1949. The Muscid Genus Ophyra in the Paciiic Region (Diptera). Proceedings of the Hawaiian Entomological Society, 13(03): 423-432.

28. Farkas, R., and Jantnyik, T. 1990. Laboratory studies on Hydrotaea aenescens as predator of house fly larvae (Diptera: Muscidae). Parasitol Hung, 23: 103-108.

29. Pont, A. C., Lole, M. J., Leblanc, H. N. and Cole, J. H. 2007. The American black dump fly Hydrotaea aenescens (Wiedemann, 1830)(Diptera, Muscidae) in Britain and Ireland. Dipterists Digest, 14: 23-29.

30. Vikhrev, N. 2008. New data on distribution and biology of the invasive species Hydrotaea aenescens (Wiedemann, 1830) (Diptera, Muscidae). ZooKeys, 4: 47.

31. Martens, C., Dekoninck, W., and Grootaert, P. 2011. Muscidae and Syrphidae (Diptera) collected by window-trapping at the IJzer estuary (Belgian coast). Bulletin van de Koninklijke Belgische Vereniging Voor Entomologie, 147: 225-232.

32. Prado e Castro, C., Serrano, A., Martins da Silva, P., and García, M. D. (2012). Carrion flies of forensic interest: a study of seasonal community composition and succession in Lisbon, Portugal. Medical and Veterinary Entomology, 26(4): 417431.

33. Kahanpää, J., and Haarto, A. 2014. Checklist of the families Scathophagidae, Fanniidae and Muscidae of Finland (Insecta, Diptera). ZooKeys, 441(441): 347-367.

34. Carvalho, C.J.B. de (Ed.) 2002 Muscidae (Diptera) of the Neotropical Region: taxonomy. Editora Universidade Federal do Paraná, Curitiba, 287 pp.

35. de Carvalho, C. J. B., Couri, M. S., Pont, A. C., Pamplona, D., and Lopes, S. M. 2005. A catalogue of the Muscidae (Diptera) of the Neotropical Region. Zootaxa, 860(1): 1-282.

36. Krüger, R. F., Ribeiro, P. B., and Carvalho, C. J. B. de. 2003. Desenvolvimento de Ophyra albuquerquei Lopes (Diptera, Muscidae) em condições de laboratório. Revista Brasileira de Entomologia, 47(4): 643-648.

37. Fernández Rivera, J. A. 2018. Análisis epistemológico (Empirismo Lógico) de la percepción de los instrumentos de evaluación empleados por los docentes a los alumnos del sexto, octavo y décimo semestre de la Escuela Profesional de Biología de la Universidad Nacional de San Agustín de Arequipa 2017. 